\title{
Contemporary Relevance of the book Guiding the Brothers on the Rules of Women Going Out Written by Sheikh Othman Bn Fodiyo
}

Usman Abubakar Daniya ${ }^{1 *}$, Maryam Hamza Khalad (Mrs.) ${ }^{2}$

${ }^{\mathrm{T}} \mathrm{PhD}$, Department of History, Usmanu Danfodiyo University, Sokoto, Nigeria

${ }^{2}$ Department of Sociology, Sokoto State University, Birnin Kebbi Rd, Sokoto, Nigeria

\section{Article History}

Received: 22.09 .2020

Accepted: 23.10 .2020

Published: 30.10 .2020

Journal homepage:

https://www.easpublisher.com/easjhcs

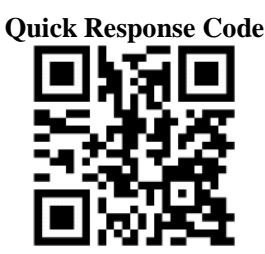

Abstract: The position and status of women in today's challenging and enterprising world has been a subject of debates and discussions. Using slogans of democracy and equal opportunities, women have for long demanded equality and rights equal to men, positions that have in many respects accommodated them in one way and in another expose them to new kinds of exploitation, at home and work. But, Islam, as a way of life, has long solved their problem by clearly spelling out the rules and guidance on how and when women should go out and participate in gatherings with men. This paper highlights and appreciates these positions as exposed by the revered Sheikh Othman Bn Fodiyo, the leader of the Sokoto Jihad in his book 'Guiding the Brothers on the Rules of Women Going Out'. Keywords: Relevance, Guiding, Brothers, Women, Going out, Sheik Othman Bn Fodiyo.

\begin{abstract}
Copyright ( ) 2020 The Author(s): This is an open-access article distributed under the terms of the Creative Commons Attribution 4.0 International License (CC BY-NC 4.0) which permits unrestricted use, distribution, and reproduction in any medium for non-commercial use provided the original author and source are credited.
\end{abstract}

\section{INTRODUCTION}

There is no doubt about the fact that in present competing and 'modern' world, the position of women, more especially on labour and equality has since become a matter of great concern especially in the 'advanced world'. The issues being raised include, among other things, leadership roles in organizations, equality of pay, and equal employment opportunity with men in all occupations. Women also demand absolute freedom to be independent. It is no surprise, therefore, that in the United States from the 1960s and ' $70 \mathrm{~s}$, Women's right movement, also called women's liberation movement has been in the vogue. It is a diverse social movement that sought equal rights and opportunities and greater personal freedom for women. This unlike the first -wave of feminism of the $19^{\text {th }}$ and early $20^{\text {th }}$ centuries that focused only on women's legal rights, the new movement touched on every area of women's experience - including politics, work, the family, and sexuality. Organized activism by and on behalf of women continued through the third and fourth waves of feminism from the mid-1990s and the early 2000 s respectively $\left[^{1}\right]$. It is, thus, no surprise, again, that many international bodies such as the United Nations have responded by giving preference to women in many

1 Elinor Burkett, 'Women's Right Movement': https://www.britannica.com/contributor/ElinorBurkett/5529. of their activities. At home, our governments have also created special ministries and organizations to take charge of women affairs and, in some places, even apply quota systems for women in political appointments. The ways of Islam as regards the position of women, however, are different. Islam, as a total way of life, has since accorded a special position to women. In Islam, the moral and spiritual state of a given society or civilization, which in turn determines its over-all internal strength and longevity, is dependent upon the status that society or civilization gives to its women. This is so because of the women's considerable influence over the basic and fundamental pillars of the society as well as their natural influence over men $\left[{ }^{2}\right]$. This work attempts an analysis of Sheikh Othman bn Fodio's explanations regarding women's going out to undertake some activities in Islam. It aims to clearly show his positions within the larger context of our cultural settings and not necessary on the western capitalist patterns that we are constantly asked to ape. To do this, the paper will first give a brief overview of the Sokoto Jihad and its leader and proceed to the main issue at hand - the Jihad leader's views on women; on

\footnotetext{
${ }^{2}$ Ibraheem Sulaiman, "Women and Society', Speech delivered at the launching of Muslim Ladies' Movement at the

School of Preliminary Studies, Kano State Institute of Higher Studies, Kano, on 26/10/1978.
} 
education, going out to market and business, going out for religious functions i.e. mosques and burial grounds and participation in ceremonies, etc. Lastly, an assessment will give a general examination of these views taking into cognizance the essence of the present social changes and organization. The end is conclusion Establishment of the Sokoto Caliphate.

Sheikh Othman bn Fodio, 'the outstanding man of the century for Sudan' $\left[{ }^{3}\right]$, was born in Gobir at a place called Marattaon Sunday 15 December $1754\left[^{4}\right]$ (29 ${ }^{\text {th }}$ Safar 1168 A.H.) [ $\left.^{5}\right]$. He came from the renowned and educated Toronkawa (Torobe) Fulani clan. He started his education under his learned father and later moved to other scholars to advance his education. Early in life, he studied Tafsir, Hadith, Law, and sometimes rhetoric. Among the famous of his teachers were his uncles: Usman Binduri, under whom he studied for about two years and Muhammadu Sambo, Muhammadu Ruji, Muhammadu Bindowo, Abdurrahman dan Hamada $\left[{ }^{6}\right]$ and Sheikh Jibril ibn Umar. The latter was a very learned man and was refuted to be the most learned man of his day in west Africa. He was, perhaps, the tutor who influenced the Sheikh most $\left[{ }^{7}\right]$. Also, he did much to put him on the path of reviving Islam $\left[^{8}\right]$.

Bn Fodiyo grew up in Hausa land. Although by the $14^{\text {th }}$ century Islam was already in Hausaland yet it was no near to be fully accepted by the majority of the populace. What seems to have happened, according to Hiskett, was that individual Muslims from peripheral areas of north Africa and Egyptian traders after the initiative patronage of the governments of the Habe States came into the Habe Kingdoms and settled thereby forming small communities that gradually began to affect the pagan peoples $\left[{ }^{9}\right]$. Islam was generally mixed with various pagan practices. Also, various forms of injustices were being obtained in the time and people were openly committing grave sins

\footnotetext{
${ }^{3}$ S.J. Hogben \&A.H.M. Kirk-Green, The Emirates on Northern Nigeria, London, Oxford University, 1966, p.116.

M. Junaidu, TarihinFulani, Zaria, Gaskiya Corporation, 1956, p.9, M .Last, The Sokoto Caliphate London, Longman, 1967, p. 3.

${ }^{5}$ S.J.Hogben, An Introduction to the Islamic States of Northern Nigeria, London, 1967, p.198.,

M. Hiskett, The Sword of Truth: The Life and Times of The Shehu Usuman Dan Fodio, London, Oxford, 1978., M.I. Talata

Mafara, DaularUsmaniyya 1 -3, Kaduna, Nadabo Print, 1999, p.19.

${ }^{6}$ Junaidu, op.cit, pp.9-10.

${ }^{7}$ Last, op.cit, pp. 5-6.

${ }^{8}$ Ibid.

${ }^{9}$ M.Hiskett, The Development of Islam in Hausaland, London, 1973, p.58.
}

without a feeling of guilt and with apparent support of government $\left[{ }^{10}\right]$.

Bn Fodio started his teaching and preaching at the age of 20 in the year 1188 A.H $\left[{ }^{11}\right](1774 / 75)\left[{ }^{12}\right]$. His duties were the following: to strengthen Islam, cleanse it from the pagan practices it was embellished, and convert the pagans. From his base in Degel, thus, he began to travel round the country to spread the true faith. He made converts wherever he went in the course of his preaching: teaching the rituals and the basic tenets of Islam. He also tried to correct the views and beliefs who were already enlightened. Abdullahi, his younger brother, records that people from the countryside came to him and remained with him as followers $\left[{ }^{13}\right]$. But bn Fodio didn't stop just around his immediate environment neither did he preach alone. He traveled with his younger brother to Kebbi and Zamfara, Zaberma and Niger, as well as Daura $\left[{ }^{14}\right]$. He was said to have great successes. But in Zamfara he had to spend five years because he found the people almost completely ignorant of Islam $\left[{ }^{15}\right]$. As Shehu became so successful that his fame spread far and wide in Hausaland and students flock to him from various parts. Being gifted with eloquence, intelligence, and high moral character he soon gathered a large following $\left[{ }^{16}\right]$. These people came to regard him as their liberator from Hausa misrule in the matter of Islamic law and as their spiritual guide to the only God $\left[{ }^{17}\right]$. Naturally, these developments alarmed the Hausa rulers who tried to curb his influence through various ways including persecution which culminated in a Jihad or holy war $\left[{ }^{18}\right]$.

When the Jihad was successfully extended, what eventually emerged as the Sokoto Caliphate encompassed 30 emirates that stretched from Konni district in the Niger Republic in the North to the Yoruba emirate of Ilorin in the south $\left[{ }^{19}\right]$ and thus culminated in

${ }^{10}$ B.A.S. Muhammad, 'Women Labour in Islam: The Views of Usman Danfodiyo', Being a Seminar Paper presented to the Faculty of Social Sciences and Administration, UDUS, Sokoto, 22/09/1998

${ }^{11}$ Abdullahi Dan Fodiyo, Tazyin'l-Waraqaat, trans. M. Hisket, M. Junaidu,,p.10, M.Last, p.6.

${ }^{12}$ R.A.Adeleye, Power and Diplomacy in Northern Nigeria 1804 - 1906: The Sokoto Caliphate and its

Enemies, London, Longman Group, 1977, p.12.

${ }^{13}$ Hiskett, op.cit, p..42.

${ }^{14}$ Ibid.

${ }^{15}$ Hogben, p.199, M. Junaidu, ,p.11.

${ }^{16}$ Ibrahim Sulaiman, The Revolution in History: The Jihad of Usman Danfodio, London 1986.

${ }^{17}$ Hogben, op.cit.

${ }^{18}$ B.A.S. Muhammad, op.cit.

19 M.Adamu, 'A General History of the Sokoto Caliphate', in A.M.Kani and K.A.Gandi eds, State \& Society in the Sokoto Caliphate, Sokoto 1990, p.8. 
the establishment of the 'largest, most heavily populated, most complexly organized, and the wealthiest state system in the nineteenth century West Africa, if not sub-Saharan Africa as a whole' $\left[{ }^{20}\right]$. The Caliphate reigned until 1903 when it was subjugated by the marauding European imperialist.

During his life, bn Fodio was a prolific writer who wrote over 100 works on various issues that guided and continue to guide the people of the region on various life issues. His views on women going out as expressed in his work, 'Guiding the Brothers on the Rules of Women Going Out', is the subject matter of this paper and these are highlighted in the next section.

\section{About the Book}

The title of the book is Guiding the Brothers on the Rules of Women Going Out. The date and the place of publication are not provided, from the beginning, Bn Fodio categorically stated his intentions - to correct the different opinions regarding women going out in the land of Sudan (Black nation). There are two groups, he contends: One extreme group, which was the majority, whoconsiders it permissible for women to go out for their needs generally like men, with or without valid excuses. The other group went to the opposite extreme, saying that it is not permissible to go out for any of their needs generally, with or without any legal excuse. This is also wrong and the advocates of this view are the minority. "They introduced these ideas into our present nations and in recent times' $\left[{ }^{21}\right]$. The Sheikh says that his intention was to advise all and establish a balance between the two extremes and give details on the rule of women going out based on the statements of the scholars of Sunnah. This is for the truth to manifest itself and being practical in calling all those who sent to the extremes to return to the middle way. This would allow women to go out and take care of their needs with a legal necessity or excuse which can be justified $\left[{ }^{22}\right]$. The Sheikh then went step by step to classify women going out into twelve types and arranged them in chapters for easy reference. He explains his positions as follows:

\section{Seeking for Obligatory Knowledge}

Islam, in theory as well as practice, has always promoted knowledge. Therefore, in Islam, the search for education is compulsory for both men and women. In fact, it is even more so with women since, as it is

20 M.Watts, Silent Violence:Food, Famine and Peasantry in Northern Nigeria, Berkely\& Los Angeles, 1983, p.149.

${ }^{21}$ Sheikh Othman bn Fodiyo, 'Guiding the Brothers on the Rules of Women Going Out', trans by Y.I. Nabingo, in

A.B. Yahaya ed, Selected Writings of Sheikh Othman bn Fodiyo, Vol. 3, Gusau, ND, p.333.

${ }^{22}$ Ibid. widely recognized, societies whose women are sufficiently intellectually developed, and morally and spiritually sound, is bound to move fast in the development and quest for happiness. Correspondingly, a society consisting of ignorant and enslaved women will continue to move backward until it is left behind by other societies $\left[{ }^{23}\right]$. The Shari'ah explicitly prescribes that the search for knowledge is compulsory for women, in the same way, it is for men, and indeed the obligation to seek education is pre-eminent over marriage $\left[{ }^{24}\right]$. The first verses of the Quran began with the word:

Read. Read in the name of thy

Lord who created; [He] created the human being from blood clot. Read in the name of thy Lord who taught by the pen: [He] taught the human being what he did not know $\left[{ }^{25}\right]$.

In the same vein, the Prophet of Islam (saw) has also emphasized the importance of seeking knowledge. Anas ibn Malik reported: The Messenger of Allah, peace and blessings be upon him, said, "Seeking knowledge is an obligation upon every Muslim" $\left[{ }^{26}\right]$.

It is apparent from the Holy Qur'an and Hadiths that the acquisition of knowledge is of women is obligatory for women in the same way as in the case of men.

Following the injunctions of the Qur'an and the sayings of Prophet Muhammad, Sheikh Othman bn Fodio asserted that it is obligatory for all who have attained the age of religious responsibilities, male or female to learn necessary things about the affairs of faith $\left[{ }^{27}\right]$. He also emphasized women getting an education at all possible costs as her 'staying at home in ignorance does not benefit her except may be to go to Hellfire' $\left[{ }^{28}\right]$. He concluded that one must allow his wife to go out and seek for knowledge if he cannot teach her.

While going out to seek education, however, the class must be either all-female or they are behind a veil in a male class. It is forbidden if they can get the teaching from their husband or if in a male class without a veil $\left[{ }^{29}\right]$. The Sheikh cited Buhari who reported that Sayyid Ahmad bn SulaimanAzzahid $\left[{ }^{30}\right]$

\footnotetext{
${ }^{23}$ IbraheemSulaiman, op.cit.

${ }^{24}$ Ibid.

${ }^{25}$ Quran 96: 1-5.

${ }^{26}$ Sunan Ibn Mājah 224

${ }^{27}$ Ibid.

${ }^{28}$ Ibid, p.335.

${ }^{29}$ Sheikh, op.cit, p.334.

${ }^{30}$ Ibid.
} 
used to admonish women setting aside for them a day to teach them the rules of religion as well as their religion from scholars when none among their husbands taught them $\left[{ }^{31}\right]$. During the life of the Prophet, Abu Sa'id al Khudri reports that some women said to the Holy Prophet: 'men have gone ahead of us (in terms of acquisition of knowledge). Therefore appoint a special day for our benefit as well.' The Holy Prophet appointed one day for them. He would meet them on that day, advise them and educate them about the commandments of Allah Almighty $\left[{ }^{32}\right]$. In addition, women must seat behind a veil which must be raised between men and women to prevent them from having visual contact and when women scholars talk to men, it must be behind a veil as well.

To the Sheikh, however, going out for purposes like a general lecture for women, as men do is not allowed. In Ihya, he reported that "going out for purposes like a general lecture for women" is not allowed. He mentioned some scholars such as bin Arafat, al-Mukhtasar, Al-khorash, Abdul-Baaq, Ashabrakhiti as well as al-Mukhtasar who shared a similar view. Contrarily, it is compulsory for her to go out and ask scholars if her husband cannot teach her. However, if the husband is teaching her, she does not need to go out and ask scholars even if his knowledge is limited. Instead, he should ask on her behalf and deliver the answer to her. Otherwise, she must go out and the husband is sinning by preventing her $\left[{ }^{33}\right]$. It is also incumbent on the judge to force him to convey knowledge to her on things like expenditure, and if he does not do, then the judge should allow her to go and seek for knowledge. From all these, one will thus realize that nothing and nobody prevents a woman/wife from going to gatherings of knowledge, zikr, and admonitions - going out to learn fard is an obligation if their husbands cannot teach them, whether the gatherings are solely female or they are behind the veil with men. It is forbidden if they get to learn from their husbands to go out or if the gathering is for men without a veil $\left[{ }^{34}\right]$.

\section{Going out for Defection}

In Islam, it is quite allowed for women to go out to answer the call of nature if they do not have toilets in their home. However, if they have, it is haram (forbidden), according to Ibn Hajar $\left[{ }^{35}\right]$. Bukhari reported a hadith from A'ishat that the wives of the prophet (saw) went out in the night to answer the call of nature over the sand. In Sahih Bukhari, Aishat reported the Prophet to have said: "permission has been given to you to go out for your needs (the "you" is plural for

\footnotetext{
31 Ibid.

${ }^{32}$ Narrated by al-Bukhari in al-Sahih, 1-50

${ }^{33}$ Sheikh, op.cit, p.334.

${ }^{34}$ Ibid.

${ }^{35}$ Cited by Bn Fodio, Ibid, p.338
}

women). Hashim says "he means defecation $\left[{ }^{36}\right]$." The Sheikh strongly agreed to these but added that in all cases, women must cover their faces. In anyway, women going out for defecation did not continue because soon after toilets were built in the houses and they stopped going out except for a necessity.

\section{Going out for Obligatory Prayer}

Islam also has a way of women going out to the mosque to perform sallatfardh (obligatory prayer). There is no doubt that a woman's prayer in her house is better for her than praying in the mosque, as is indicated by the Sunnah of the Prophet. He said: "Do not prevent your women from going to the mosque, even though their houses are better for them $\left[{ }^{37}\right]$." The Sheikh, certainly, noted this but went ahead to state, however, that it is haram to the young woman who has attained puberty and the popularly known by their beauty contrary to the elderly who are not popular by their beauty. It is permissible for an adult woman that has removed completely from herself the desire of a man and it is recommended for the one that men have no desire towards her $\left[{ }^{38}\right]$. The Sheikh cited Gazzali in Ihya who said that "we must stop women from going out to the mosque for prayer if there is a fear of fitna (trouble) from them $\left[{ }^{39}\right]$." On the whole, it seems the Sheikh agreed with Al-Mukhtar on the going out of an adult woman for Eid and prayer for rain and a young woman to a mosque provided that she is in advanced age and whom men do not desire. It is also mandub for her to go to Eid prayer and prayer for rain and other obligatory prayers while the adults who are attracted to men go to the mosque for fard prayers on the conditions that they are not too youthful neither attractive and smart, otherwise, they do not go out at all.

The Sheikh also cited Al-Shabrakhitywho said in Al-Mukhtasar that scholars have made it a condition for women to go out in the night, but they should not be ornamented or perfumed. It is based on the Hadith that says that any woman that has perfumed herself should not pray Isah'i with us and that they should not be moving shoulder to shoulder with men and neither should a young woman whose temptation is feared. She should also come out in her rough clothes without apparently making up (beautifying) in such away to be noticed. As for make-up that is not noticeable to men by looking or hearing a voice, there is no problem withthat. Al-Bisatui added that she should not be famous forher beauty (to avoid troubles). All these of course in conformity with the Qur'an saying:

\footnotetext{
${ }^{36}$ Ibid., p.339.

${ }^{37}$ Reported by Abu Dawud in al-Sunan, Baab maa jaa'a fee khurooj al-nisaa' ilaa'l-masjid: Baab al-tashdeed fee dhaalik. See also Saheeh al-Jaami‘, no. 7458).

${ }^{38}$ Ibid.

${ }^{39}$ Ibid.
} 
"And tell the believing women to lower their gaze (from looking at forbidden things), and protect their private parts (from illegal sexual acts) and not to show off their adornment except only that which is apparent (like both eyes for necessity to see the way, or outer palms of hands or one eye or dress like veil, gloves, head cover, apron), and to draw their veils all over Juyoobihinna (i.e. their bodies, faces, necks and bosoms) and not to reveal their adornment except to their husbands..." [ $\left.{ }^{40}\right]$.

\section{Going out for Juma'at prayers}

On the appropriateness of going out for Jumu'at prayer, the Sheikh posited that it is forbidden for the young women whose temptation is feared and it is disliked (makruh) for the young that are not tempting. It is permissible for the elderly that are no more attractive to men. He cited Al-Kharrashiwho said on the explanation of Al-Mukhtasar that "it is detestable for a young lady whose temptation is not feared to attend it." I cannot stop her from attending it. Abdu-Baqi added in the same place that "it is permissible for the adult that is no more desired by man $\left[{ }^{41}\right]$." As for the adult, she can go for Eid prayers and is permissible. However, it is not permissible for the young especially these days when mischief is rampant. It is recommended (mustahab) for the old who have reached menopause to go to the mosque $\left[{ }^{42}\right]$.

\section{Going out for Eid Prayers}

For Eid festival prayer, the Sheikh also cited Al-kharshani while explaining Mukhtasr, where the author said the adult can go out for Eid. This means that it is permissible while it is mandub for the old, those who are no more desirable by men. Abdul Baqi said as well as Al-Kharshani on the statement of the author and the merits of the two Eid prayers, using perfume and ornament even for those who will not pray, when they go outeven though old (post-menopause) they should not use perfume and neither should they make up nor decorate themselves to avoid tempting men $\left[{ }^{43}\right]$.

\section{Going out for Prayer Seeking Rainfall}

As for coming out for prayer for rain, again, it is permissible for adults, but not for the young. Again, Danfodiyo said Abdul Baqi said in the explanation of Mukhtasar where the author discussed prayer for the rain that "they come out at Duha time (morning) on foot with sacrifice and humility comprising of old people

\footnotetext{
${ }^{40}$ Interpretation of the meaning, Qur'an: al-Noor 24:31. ${ }^{41}$ Ibid.

${ }^{42}$ Sheikh Othman..., p.340.

43 Ibid.
}

and old women." The Sheikh himself based himself on the saying of Allakhami that three categories come out for Istisqa (prayer for rain): men, those who are old enough to pray among the children, and the old women $\left[{ }^{44}\right]$.

\section{Going out for funerals and visiting ceremonies}

As for their coming out for funerals, there is an explanation for that. It is forbidden for a young woman whose temptation is feared to attend a funeral. It is, nonetheless, lawful to attend the funeral of someone very close to her whose loss is a great pain to her like father, her mother, her husband, son, daughter, sister, or brother. It is also permissible for an old woman to attend the funeral of everyone. It is detestable to others apart from them, and it is forbidden for her when there is a fear of temptation. This applies the same to visiting the graves. In any case, if they must, then they must comply with the Shari'ah such as covering themselves and behaving modestly $\left[{ }^{45}\right]$.

\section{Going out for Pilgrimage}

Going out for pilgrimage for women is as obligatory as it is for men. However, women must conform to the conditions in a few things mentioned by Sheikh Khalid in the Mukhtasar. He explained that: a "Woman is like a man except that in walking long distance and traveling by sea, except she is given special skill, backed up by a Mahram (family member to protect her) to serve as company and security." In AlIktifa', it is said that she must be "with women or men or in a congregation" $\left[{ }^{46}\right]$.

\section{Going out for Marriages}

As for going out for marriage, it is permissible if the marriage is for their relatives who insisted that they must be there and the celebration is free from evil and forbidden things. If there is evil like mixing of the opposite sex or playing musical instruments and the likes, it is forbidden. Danfodiyo here categorically, citing many sources, adduced the wife going out without covering her face, attending marriages and feasts with both men and women dancing and without covering her face and external parts of her body like the habits of the Bedouins not permissible and not accepted. The husband is under the wrath of Allah and so will be if she remains like that. On the whole, the Prophet is reported to have said that: Keep a distance between the breath of men and that of women $\left[{ }^{47}\right]$.

\section{Going out for buying and Selling in the Market and other places}

As for their going out for buying and selling in the market and other places, there is also an explanation

\footnotetext{
${ }^{44}$ Ibid., p.340.

${ }^{45}$ Ibid., p. 341.

${ }^{46}$ Ibid., p.342.

${ }^{47}$ Ibid.
} 
for that it is permissible if they could not have somebody who can do that for them like a husband or a Mahram or others among elderly women. It is forbidden if they have who can do that for them among the people mentioned above. A young girl's going out is temptation. Let her sent someone among the old women whom men will not look and neither will they bother about them and there is no more fit na in their shape or way of talking. If that is not possible, then let her get rid of her ornament. If a wife wants to buy a cloth, ornament, or other things, let the husband do that himself if he can do it, or find someone who can represent him based on the counsel of scholars. Danfodiyo fears that sitting with people without morals and others whom they have an audience with and feel comfortable with and sometimes to the extent of coming close to the possibility of committing a great sin $\left[{ }^{48}\right]$.

\section{Going out to Court}

As for going out to the court, there is also an explanation that it is permissible for the old and for the young woman that is not famous for her beauty, but not permissible for the young woman that is famous for her beauty. Moreover, it is commendable for the judge to set aside time or a day for women like Mufti and the teacher that is a specific time that he does not do proceedings excepts for women, or a specific day in which he only takes cases of women and between men and women in three stages: one day for women only, one day for men only and one day for both men and women $\left[{ }^{49}\right]$. As for the beautiful young woman, she does not come, but she should delegate $\left[{ }^{50}\right]$.

\section{Going out to visit}

As for coming out for visit, it is permissible if they are going out to visit their relatives among women or their Muharims among men when the need presents itself. It is forbidden if their going out is to visit their beloved ones among men even if they will meet with strangers mixed with their relatives like cousins (paternal and maternal). Husbands do not have the right to prevent the parents and sons of his wife from other men from visiting her. The Shari'at recommended the observance of duties of kinship and that has become a habit. It is thus incumbent on the husband to allow his wife to receive her relatives among women in her privacy, but not the men, except for the Maharims. These include her brother, her paternal and maternal uncles, and her nephew from her brother or sister. He cannot prevent her from going out with them, but by preventing them does reach the level of sin he gets from preventing her parents because indeed there is no sin except in them $\left[{ }^{51}\right]$. However, when going out for a

\footnotetext{
${ }^{48}$ Ibid, p. 343

${ }^{49}$ Ibid., p.343.

${ }^{50}$ Ibid.

${ }^{51}$ Ibid, p.344.
}

journey, it is not permissible except with husbands or Maharims or a trusted company. This is wajib. A woman should also not travel for half-day, two or three days, or even a night without a related company $\left[{ }^{52}\right]$.

\section{Review of the Main Thesis}

In Islam, the principle of women going out rests on legal necessity which is sometimes worldly in nature. These amongst others include going out for their basic needs, while some other times the necessity is religious in nature like going out to ask scholars if their husbands cannot teach them. As far as the Sheikh is concerned, women's going out generally is forbidden except where it is absolutely necessary. He, in most cases, reached his explanations using the sayings of the Holy Prophet and different kinds of arguments and opinions of scholars. He cited this hadith:

"Keep distance between the breath of men and women because if you keep the nerve of a man in the east and the nerve of a woman in the west, they will desire each other, what more if they are engaged in hugging and jostling and other shameless acts" $\left[{ }^{53}\right]$.

The Sheikh's brother, Abdullahi, however, was stricter on women going out. In fact, he stated in his Kitab WathiqatulJawabi $\left[{ }^{54}\right]$ that Allah will not accept the worship (i.e.prayers, fasting, alms giving and pilgrimage) of anyone who allows his wife to go out. He even goes to the extreme of considering such a person as non-Muslim $\left[{ }^{55}\right]$. But the Sheikh disagrees and said that such acts are only grave sins and that those who commit them may not remain permanently in hell $\left[{ }^{56}\right]$.

Secondly, it is incumbent upon the husband to teach his wife if she is ignorant of the Islamic ruling. If he does not teach her, she should ask him to do so. If he does not know, he should either ask and inform her or give her permission to learn. However, if he does not allow her, and she goes out without his permission, it is permissible. Women have rights on issues of religion which they were created for...Allah says: "I did not create Jinni and mankind except for them to worship me $\left[{ }^{57}\right] . "$

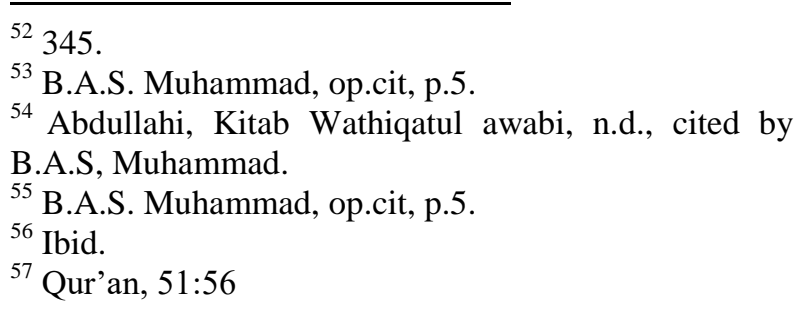


However, in Ihya'usSunnati $\left[{ }^{58}\right]$ the Sheikh says that in the event it becomes necessary for a woman to leave her matrimonial home for work or anything, certain inappropriate practices must be avoided. Also, a man should not be secluded with a woman who is not his wife or muharramat into places where they cannot be sighted by passers-by even if they have no intention of sinning. A woman should not appear wearing a light close or one that exposes her body. She should not also act provocatively or suggestively or speak with an exaggerated voice. The Sheikh adds that a woman can only go outside and work or conduct business under the above conditions if she has no one to provide for her or if she is old or ugly. In the end, however, the Sheikh points out that it is still better if the woman does not go out even if she satisfied these conditions. Hishardposition is summarized in the verses from his WakarLarura:

"O you women do not go out without aim,

Unless a slave or freeborn below puberty,

Under the pressure of compulsion and not atrocities,

All women except old ones are included,

Except one under necessity;

Unless for searching for compulsory knowledge,

Properly covering her body for God's pleasure, Isolation (with men) is not wanted and not allowed,

Exposure of the body is not rewarded,

She should ask on what constitutes necessity,

One who has a person to assist her,

Should not go out but rest in her room,

To practice her ibada and there is enough for her,

Unless there is no husband or brother,

To teach her then this constitutes a necessity $\left[{ }^{59}\right] . "$

As stated above, the Sheikh talks about compulsory learning. However, it appears, even this is confined exclusively to learningfard al-'ayn [ $\left.{ }^{60}\right]$. In IrshadulIkhwaniilaAhkamHuruinNiswani [ $\left.{ }^{61}\right]$, the Sheikh adds that at a place of learning, women must be separated from men and they should not see each other.

${ }^{58}$ Usman Danfodiyo, Ihya'usSunnati, n.d., trans. In to Hausa by Ahmed Sabir 1984, BUK

59 Usman Danfodiyo, WakarLarura, Hausa version, N/D, Department of Languages, Abdullahi Bayero College, Kano, cited by Muhammad, op.cit.

${ }^{60}$ Individual duty or fard al-'ayn relates is required to perform, such as daily prayer (salat), and the pilgrimage to Mecca at least once in a lifetime (hajj). Sufficiency duty or farḍ al-kifāya is a duty which is imposed on the whole community of believers (ummah).

61 Usman Danfodiyo, Irshadullkhwaniila AhkamHuruinNiswani, n.d., trans. Into English by M.I. T/Mafara, Sokoto 1983.
However, as expressed by his brother, Abdullahi $\left[{ }^{62}\right]$ it is agreed that in the event separation between men and women are not obtainable, the learning of fardainih is the more important consideration $\left[{ }^{63}\right]$.

\section{The relevance of the Book}

Islamic Law has utilized as a general maxim the Prophet Muhammad'sstatement, "Women are the equal partners of men." ${ }^{64}$ This means that as a general principle, all of the rulings in Islam apply to both men and women unless otherwise specified due to a relevant gender difference. However, Islam came to protect women and their honor, and prescribed rulings that take care of that. Allah says: And stay in your houses. ${ }^{65}$ Based on this, the general principle is that women should stay at home and not go out except for essential reasons or cases of need. Islam states that a woman's prayer at home is better for her than her prayer in the mosque.

This does not mean that women have to remain prisoners in the house. Islam permits them to go to the mosque and has made Hajj and Umra, Eid prayers, etc. obligatory for them. Among the kinds of going out that are prescribed are going to visit their family and mahrams, and going out to ask religious questions from people of knowledge. Women are also permitted to go out for their own needs.But all of these have to be within the limits and conditions set out in Shari'a, such as being accompanied by a mahram when she travels or being assured that her route is safe when she moves about in her city or locality. She should also go out wearing a complete hijab, and she should not be wearing make-up, adornments, or perfume.

In today's world, to presume that Western open-mindednessis the only yardstick that represents the standard of moral progress to which all other societies must accept is nothing short of cultural imperialism that not only ignores and marginalizes the experiences of women of other cultures but also calls upon them to erase their identities and embrace the 'superior' values of European/North American women.

In any case, critics have argued that far from representing a bastion of moral enlightenment, the modern Western value system is riddled with internal contradictions such as promoting a culture of promiscuity and sexual exploitation of women while simultaneously aiming to desexualize and de-objectify

\footnotetext{
${ }^{62}$ A. Abdullahi, Tazyin al-Waraqat, ed and trans. By Hiskett, Ibadan 1983.

${ }^{63}$ Muhammad, op.cit.

${ }^{64}$ Sunan al-Tirmidhī, 113

65al-Ahzaab 33:3
} 
male perceptions of women $\left[{ }^{66}\right]$. Also, in attempting to dismantle the normal standard of the male breadwinner and female homemaker, women have poured into the labor market, galvanizing the engines of capitalism ${ }^{67}$ in ways that have unfairly burdened some women [ $\left.{ }^{68}\right]$. Islam does not recognize this and clearly spelt that where conditions necessitate that a woman must go out and work because she has no one to provide for her and she has nothing to sustain herself, the work situation must be such that the following are avoidable; isolation with men, chatting with men, exposure of her body and attractive behavior $\left[{ }^{69}\right]$.

Islam recognizes sexual attraction between men and women and teaches that it must be controlled to provide a just social arrangement where economic goals include material and spiritual considerations with the latter being the overriding consideration where there exists a conflict between the two. In a recent survey in the US, a positive correlation was observed between more women in the workplace and a rise in adultery. They conceded that more women in the workplace meant greater access to men and more chances for affairs $\left[{ }^{70}\right]$.

Also, today's workplace has become the commonest spot for married individuals to meet affair partners. More men and women are breaking their marriage vows by engaging in office friendships that slowly become romantic relationships. In her book, Not 'Just Friends' $\left[{ }^{71}\right]$, Dr. Shirley Glass says, "The new infidelity is between people who unwittingly form deep,

${ }^{66}$ For a discussion of such arguments, see Anne Barnhill, "Modesty as a Feminist Sexual Virtue," in Out From the Shadows: Analytical Feminist Contributions to Traditional Philosophy, edited by Sharon L. Crasnow and Anita M. Superson (New York: Oxford University Press, 2012), pp. 115-137. From a social psychology perspective, see Cikara, M., Eberhardt, J. L., \& Fiske, S. T. (2011). From agents to objects: Sexist attitudes and neural responses to sexualized targets. Journal of Cognitive Neuroscience, 23, 540-551.

${ }^{67}$ Fraser, Nancy. How feminism became capitalism's handmaiden - and how to reclaim it. The Guardian. Oct 14 ,

2013. https://www.theguardian.com/commentisfree/201

3/oct/14/feminism-capitalist-handmaiden-neoliberal

${ }^{68}$ Slaughter, Anne-Marie. Why Women Still Can't Have it

All. The Atlantic. 2012. https://www.theatlantic.com/ma gazine/archive/2012/07/why-women-still-cant-have-itall/309020/

${ }^{69}$ Ibid., p.9.

${ }^{70}$. Adler, 'Infidelity in the 90s', Newsweek Magazine, Vol. CXXVIII, No. 14, New Yolk, 1998, cited by Muhammad, ibid.

${ }^{71}$ Shirley Glass, Not Just Friends, USA, Simon \& Schuster, 2007 passionate connections before realizing that they've crossed the line from platonic friendship into romantic love. Eighty-two percent of the 210 unfaithful partners I've treated have had an affair with someone who was, at first, "just a friend."' From 1991 to 2000, Glass discovered in her practice that 50 percent of the unfaithful women and about 62 percent of unfaithful men she treated were involved with someone from work. "Today's workplace has become the new danger zone of romantic attraction and opportunity $\left[{ }^{72}\right] . "$

From these pieces of evidence it appears therefore that many factors can play a role in causing infidelity. Islam has provided some basic rules to help avoid the new infidelity by prohibiting much intermingling between sexes.

\section{CONCLUSION}

In conclusion, this paper has demonstrated that the so much propaganda about women's liberation and rights, freedom over work and living expressed by women activists and movements are certainly not in agreement with the way of Islam. Islam greatly protects Muslim women. It provides for them to go out only when it is necessary and put most of their burden on men. This no doubt affords tranquility in our societies thereby preventing sexual harassments and infidelity in the society. This is certainly the view of Danfodiyo, as it is generally in Islam. 